\title{
Treatment of intractable orofacial infection: Case reports
}

\author{
Dong-Woo Kang ${ }^{1}$, Pil-Young Yun ${ }^{1}$, and Young-Kyun Kim ${ }^{1,2 *}$ \\ ${ }^{1}$ Department of Oral and Maxillofacial Surgery, Section of Dentistry, Seoul National University Bundang Hospital, Seongnam, Republic of Korea \\ ${ }^{2}$ Department of Dentistry and Dental Research Institute, School of Dentistry, Seoul National University, Seoul, Republic of Korea
}

In severe cases, intractable infections in the orofacial area can lead to breathing difficulties due to closed airway, mediastinitis, and spread of infection along the blood vessels. Moreover, these conditions lead to sepsis, brain abscess, and cavernous sinus thrombosis, which can be life-threatening. The objective of this study was to evaluate the treatment of dental care and emergency situations of patients with intractable infections. In this study, two cases of intractable infection that occurred in multiple orofacial spaces were treated well through incision and drainage under general anesthesia, tracheostomy to secure an emergency airway, and active cooperation with other medical departments. Further, it is important to perform early incision and drainage with a high dose of antibiotics, obtain a discharge route with drainage, and manage infection through daily massive irrigation and dressing.

Key Words: Intractable infection, Odontogenic, Orofacial

(c) This is an open-access article distributed under the terms of the Creative Commons Attribution Non-Commercial License (http://creativecommons.org/licenses/by-nc/4.0) which permits unrestricted noncommercial use, distribution, and reproduction in any medium, provided the original work is properly cited.

\section{서 론}

구강악안면 부위의 감염성 질환은 대부분 국소화되면서 통상 적인 치주 처치나 발치, 절개 및 배농술, 약물 치료 등으로 잘 치 유된다. 하지만 근막간극을 타고 감염이 확산되면 기도 폐쇄로 호흡 곤란을 유발하거나 종격동염을 발생시킬 수도 있고, 림프 절과 혈행을 따라 확산되면서 패혈증이나 뇌농양, 해면정맥동 혈전증, 감염성 심내막염 등을 야기하여 생명을 위협할 수도 있 다[1-4]. 구강악안면 부위에서 감염이 발생하는 원인은 치성 감 염(odontogenic infection)이 대부분이며, 상악동염, 인두염, 이 염, 편도선염, 외상, 타액선염, 감염성 낭종 등 다양하게 존재한 다[5-8]

감염은 조기 진단이 매우 중요한데 우선 환자의 생징후를 잘 살펴보고, 전신무력감, 열감, 피곤한 느낌, 부종, 파동성 종창 (fluctuation), 이환된 부위의 경결감, 혀의 거상 여부, 연하 장 애, 개구제한, 통증, 탈수 증상 여부, 감염의 원인 등을 면밀히 관찰하여 감염의 심각성 정도를 파악해야 하고 환자의 병력이 나 숙주의 방어기전(host defense mechanism)을 평가해야 한 다[9].

감염에 대한 치료는 가능하면 조기에 절개 및 배농술을 통하 여 감염이 해소될 수 있는 통로를 확보하고 농이 나오지 않더라 도 감압의 효과를 통해 통증을 감소시키고 감염의 확산을 방지 할 수 있다[1,10]. 또한 고농도의 항생제 및 수액 영양 요법이 병 행되어야 한다.

저자들은 고령의 조절되지 않는 당뇨 및 신장 질환을 가진 환 자의 우측 상악 제 1 대구치와 우측 하악 제 3 대구치의 치근단 농 양이 원인이 되어 협부간극, 악하간극, 설하간극, 익돌하악간극, 교근간극, 측두간극까지 감염 확산된 증례에서 적극적인 절개

Received August 22, 2019; Revised September 14, 2019; Accepted October 4, 2019

*Corresponding author: Young-Kyun Kim, Department of Oral and Maxillofacial Surgery, Section of Dentistry, Seoul National University Bundang Hospital, 82 Gumi-ro 173beon-gil, Bundang-gu, Seongnam 13620, Republic of Korea.

Tel: +82-31-787-7541, Fax: +82-31-787-4068, E-mail: kyk0505@snubh.org 
및 배농술과 기도 폐쇄를 막기 위한 기관절개술을 시행하여 잘 치유시킬 수 있었다. 두 번째 증례는 알코올성 간경화를 않고 있 는 52세 남환이 좌측 하악 제 2 대구치의 치근단 병변이 원인으 로 관여하여 악하간극, 교근 간극, 설하 간극, 이하간극, 익돌하 악 간극, 후인두부로 감염이 확산되어 절개 및 배농술과 기관절 개술을 시행하였고, 급작스러운 위혈관 출혈로 인한 토혈에 대 해 타과와의 적극적인 협진으로 경동맥혈관색전술(embolization)을 통해 응급상황을 해결하였다. 하지만 퇴원 후 이차적인 감염 발생으로 좌측 하악지 및 과두 부위의 병적 골절(pathologic fracture)과 골수염 증상으로 개구제한과 전치부 개방교합 이 발생하여, 적극적인 개구 운동과 항생요법으로 치료한 증례 를 경험하였기에 두 증례를 문헌고찰과 함께 보고하고자 한다.

\section{증례보고}

\section{증례 1}

74세의 남환으로 기저질환은 고혈압, 당뇨, 통풍, 신장 질환 이 있었으며, 1 주 전부터 하악 우측 구치부의 통증과 함께 4 일 전 악하부 종창, 우측 눈 주위 부종을 주소로 응급실에 내원하였 다. 3년 전 우측 천부 대퇴부 동맥(superficial femoral artery) 이 폐쇄되어 혈관형성술을 시행한 병력이 있었다.
내원 당시 혈압은 $144 / 90 \mathrm{mmHg}$, 맥박은 86회/분, 호흡 수는 18 회/분, 체온은 $36.7^{\circ} \mathrm{C}$ 였다. 극심한 개구제한을 보였고, 하악 우측 제 3 대구치를 지대치로한 가철성 의치가 환자의 요구에 따 라 고정된 상태로 있었다. 혈액 검사상 white blood cell (WBC) $15,200 / \mu \mathrm{L}, \mathrm{c}-$ reactive protein (CRP) 21.9 가 관찰되었고, 즉 시 하악 우측 전정부위에 국소마취하에 절개 배농술을 시행하 고 경구 항생제를 투약하였다. 당시 파노라마 방사선 사진에서 \#16 부위의 치주병소와 \#17 캔틸레버 보철물을 관찰할 수 있으 며, \#48 부위도 치근단 병소가 관찰되었다(Fig. 1). Computed tomography (CT) 사진에서는 \#48과 \#16의 치근단 병소 기원 으로 추측되는 농양 소견이 관찰되었고, 우측 협부간극, 악하간 극, 설하간극, 익돌하악간극, 교근간극, 측두간극까지 농양이 확 산되었다(Fig. 2). 다음날 우측 귀부위로 종창이 확대되었고 혈 액검사는 WBC 14,900, CRP 24.9로 매우 높은 소견을 보였고 혈당이 214, 316, 280 등으로 조절되지 않는 양상을 보여, 상악 구치부에 국소마취하에 추가 절개배농술을 시행하였고, 하악 국소의치는 제거한 후 입원치료를 시작하였다.

6시간 간격으로 ampicillin/sulbactam을 투여하였고, 혈당 수치가 210-320 mg/dL 및 당화혈색소(HbA1c)는 7.5\%로 조절 되지 않아 내분비 내과에 의뢰하여 alberti's regimen을 시행하 였다. 추가로 우측 구강외 절개배농술을 시행하여 다량의 농을 배출하였다. Chest CT상에서 폐혈성폐렴(septic pneumonia),
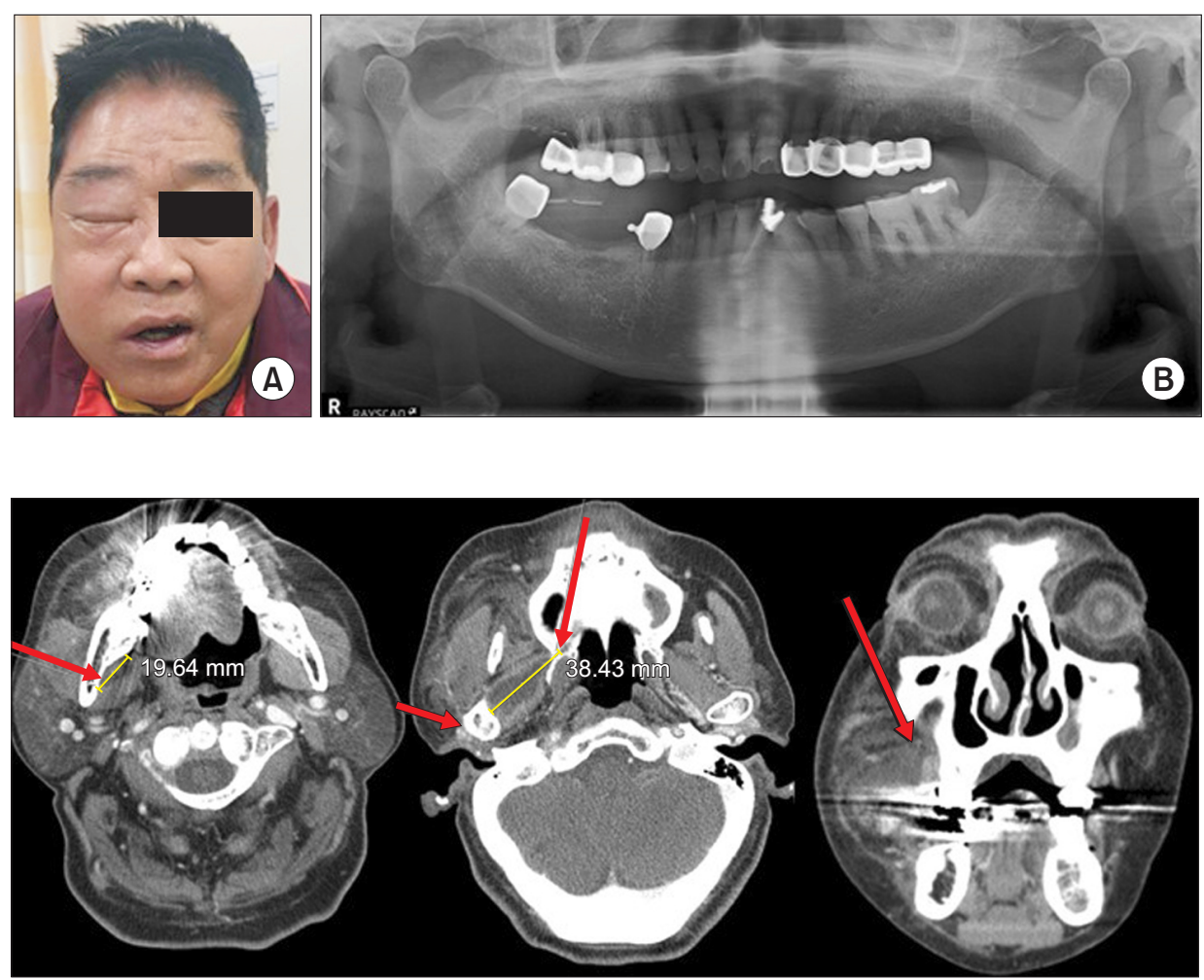

Fig. 1. (A) Progressive right cheek and periorbital swelling at the emergency department, (B) parnoramic radiograph at initial presentation. A removable partial denture was removed state. Note the periapical radiolucency on $\# 16$ and 48 tooth.
Fig. 2. The computed tomography scan showing fluid collection in buccal, submandibular, sublingual, parapharyngeal space. 
진균감염(fungal infection) 혹은 결핵 의심 소견이 있어 호흡 기 내과에 의뢰하였다. 호흡기 내과에서는 증상이 미약한 상태 이고 전신적인 상태를 고려했을 때 3회 가량 결핵균 배양 검사 (acid-fast bacilli culture)를 시행한 후에 재평가 하기로 하였 다.

입원 1 주일 동안 하루에 2회씩 창상 소독 및 수액과 고농도 항생제 요법 치료를 시행하였고, 혈액 검사상 CRP는 12-16, WBC는 11,000-15,000 정도를 보였다. 입원 8일차에 추가 neck CT 촬영 결과 우측 안와벽까지 봉와직염이 확산되었고 측 두근 쪽으로 새로운 농양이 형성되고, 측인두부의 농양의 크기 가 증가하였다(Fig. 3). 안과에 검진의뢰를 하여 산동 후 검진한 결과 양안에 안구 침범 소견은 없다는 답변을 받았다. 이후 전 신마취하에 우측 측인두부, 악하부, 협부간극의 절개 및 배농술 을 시행하였고 하악 우측 제3대구치는 발거하였다. 수술을 마치 고 기도확보를 위해 삽관을 유지한 상태로 중환자실에 입실하 였고 진정 상태를 유지하였다. 수술 직후 혈액 검사 상 $\mathrm{WBC}$ 는 28,700, CRP는 14.8 을 보였다.

입원 9일차에 원활한 기도확보 및 일반 병실로의 전동을 위 하여 중환자실에서 midazolam으로 진정시킨 후 bedside tracheostomy를 통해 기도를 확보하였다. 입원 10일차에는 WBC $17,500, \mathrm{CRP} 20.4$ 상태를 보였다. 영양 공급을 원활하게 하기 위해 영양집중지원팀에 의뢰하여 total parenteral nutrition 제
작하여 투여하였다. 증가된 CRP와 함께 저알부민혈증(hypoalbuminemia)을 보였고 혈당 조절도 continuous IV insulin therapy로 지속하였다. 입원 11일차에 일반 병동으로 전동하였 고, WBC 16,500, CRP 21.6을 보였다. 입원 12일차(전신마취 수술 후 4일차)부터 다량의 농 배출과 함께 증상이 많이 호전되

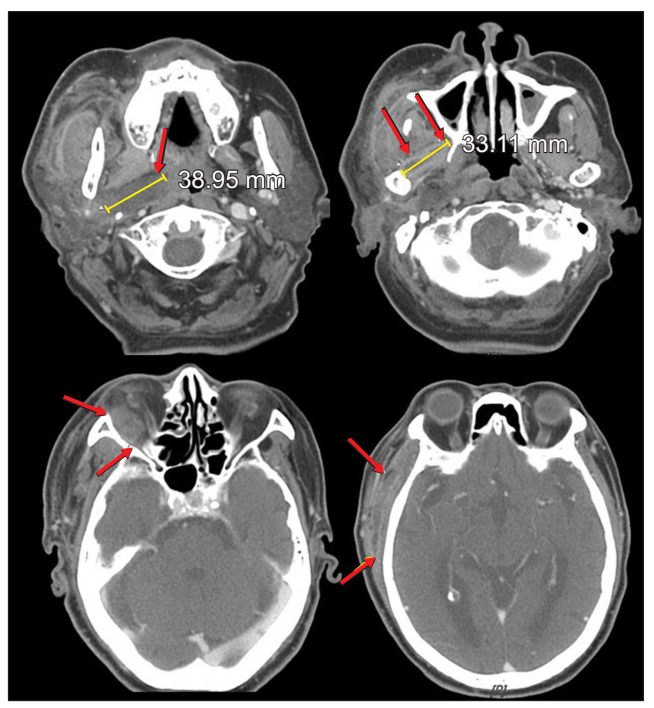

Fig. 3. The computed tomography scan showing additional fluid collection in temporal area.

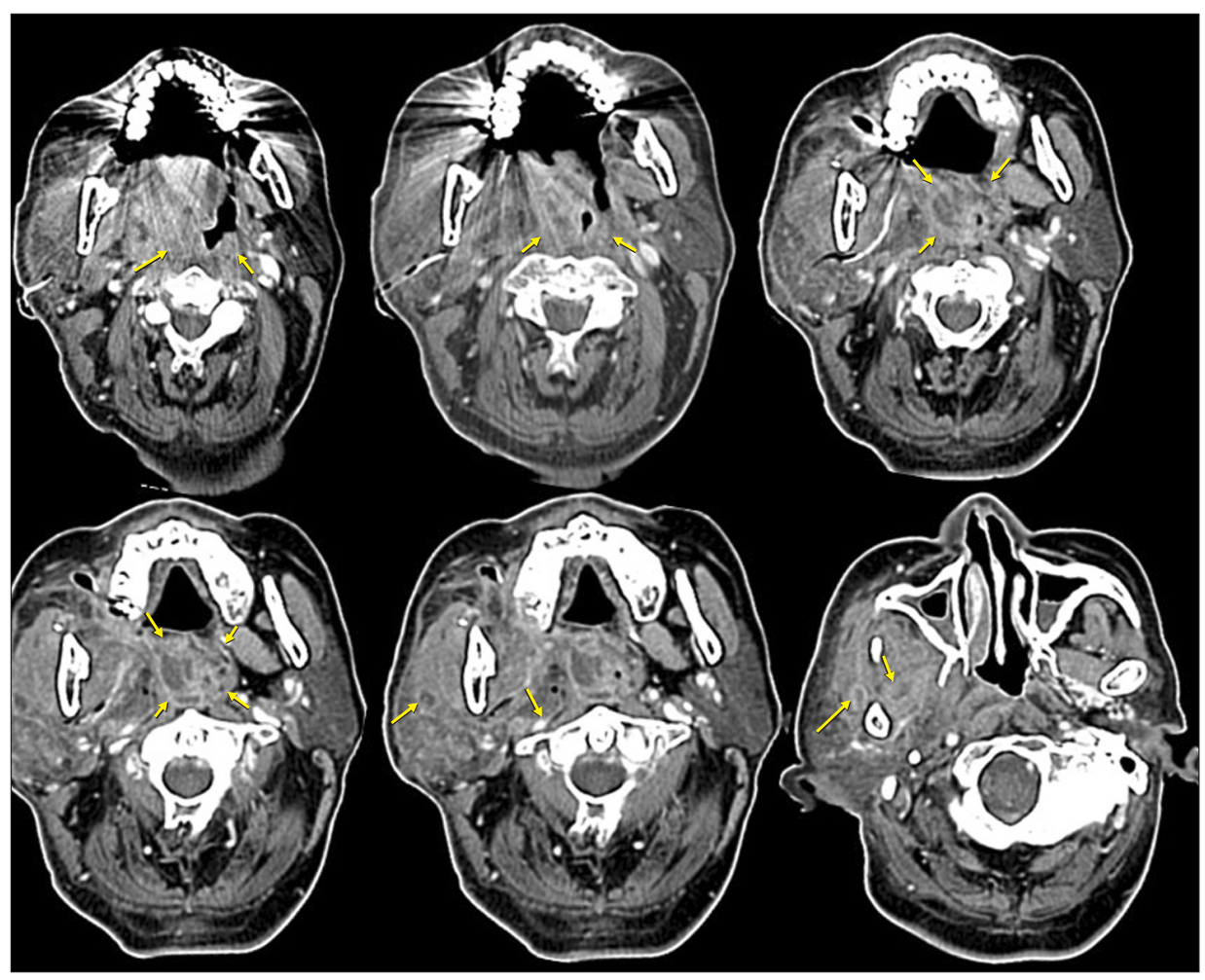

Fig. 4. The computed tomography scan showing reduced fluid collection. 
면서 감염 조절이 되기 시작하였고 CRP 9.69, WBC 12,700을 보이며, CT소견상에서도 기도는 아직 좁은 상태이나 농양의 크 기는 많이 작아진 것을 확인할 수 있었다(Fig. 4). 그 이후 CRP 수치도 점차 낮아지면서 입원 20일차부터는 CRP 2미만을 유지 하였다. 총 1 개월 가량 입원한 후 증상이 호전되어 T-cannula 를 제거하고 창상을 봉합한 후 퇴원하였다. 퇴원 3 개월 후 개구 량은 $38 \mathrm{~mm}$ 가량으로 회복되었다.

\section{증례 2}

52세의 남환으로 기저질환은 알코올성 간경화 및 B형 간염이 있었고, 1 주 전부터 좌측 하악 구치부에 염증이 있어 개인치과 에서 절개배농술을 시행하였고 종창성 부종이 점차 심해져 응 급실로 내원하였다. 내원 당시 혈압은 $146 / 84 \mathrm{mmHg}$, 맥박은 82 회/분, 호흡 수는 14 회/분, 체온은 $36.1^{\circ} \mathrm{C}$ 였고 심한 개구제한 과, 좌측 악하부, 협부 부종이 관찰되었다(Fig. 5). 혈액 검사 상

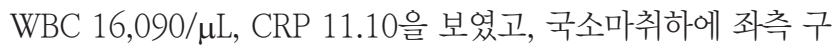
치부 전정부위에 절개 배농술을 시행하고 경구 항생제를 투여 한 후 경과를 관찰하였다. 당시 파노라마 사진에서는 근관치료 된 \#37 치아의 치근단 병변이 관찰되었다(Fig. 5). CT상에서는 악하간극, 교근 간극, 익돌하악간극에 농양이 다발적으로 형성 되어 있었다.

4일 후 증상이 더욱 악화되어, 심한 부종과 통증, 개구제한, 연하곤란, 호흡 곤란 등의 증상을 호소하면서 응급실에 재내원 하였다. 내원 당시 혈압은 $162 / 82 \mathrm{mmHg}$, 맥박은 98회/분, 호 흡 수는 17 회/분, 체온은 $39.1^{\circ} \mathrm{C}$ 로 높은 혈압과 체온을 보였고, 혈액검사는 WBC 12,480, CRP 10.1을 보였다. CT상에서는 악 하간극, 교근 간극, 설하 간극, 이하간극, 익돌하악 간극, 후인두 부의 농양의 크기 및 정도가 조금 더 확산되었다(Fig. 6). 좌측 악하부위에 추가 절개 및 배농술을 시행한 후 감염에 대한 집중 관리를 위해 입원하였다.

입원 1일차에 위혈관 출혈로 인한 심한 토혈(hematemesis) 이 발생하여 중환자실로 옮긴 후 단위 동맥(short gastric ar- tery) 출혈이 의심되어 수혈과 함께 경동맥혈관색전술을 시행 하였고, 위장관출혈과 심한 개구제한으로 기도확보를 위한 삽 관은 어려운 상태여서 midazolam으로 진정마취를 한 후에 응 급 기관절개술을 시행하였다. 입원 2일차에 전신마취하에 응급 으로 좌측 측인두부, 악하부, 협부간극에 절개 및 배농술을 시 행하여 다량의 농을 배출시켰다. 전신마취된 상태에서 술 후 최 대 개구량은 $35 \mathrm{~mm}$ 를 보였다. 감염내과와 협진하에 항생제는 ceftriaxone과 metronidazole을 함께 투여하였다. 수술 후 중환 자실에서 회복 중에, 갑작스러운 고열, 탈수, 의식 혼탁(disorientation), 호흡 부전 등을 보여, 기계환기(ventilator)를 유지하 여 의식과 호흡이 호전되었고, 2 일 뒤 종합내과로 전과하여 흥 부 $\mathrm{x}$-ray에 관찰되는 폐 부종(pulmonary edema)에 대해서 경 피적 도관 배액술(percutaneous catheter drainage) 혹은 복수 천자(ascites tapping)를 시행해야 할지 경과 관찰을 하였으나, 환자 및 보호자의 거부로 이뇨제 약물로 치료하면서 경과를 관 찰하였다. 이후 혈류의 안정성 여부를 집중치료실에 입원하여 집중 관찰하였다. 구강악안면외과에서는 하루 2회씩 지속적인 창상 소독 및 항생제 치료를 지속하였다. 내과 입원 10일 후 상 태가 호전되어 구강악안면외과로 다시 전과되었으며 입원 21 일차까지 적극적인 드레싱과 항생요법으로 증상이 호전되어 Tcannula를 제거한 후 퇴원하였다.

퇴원 1개월 후 폐구 시 $3 \mathrm{~mm}$ 가량 전치부 개방교합이 관찰 되었고, 수동적 최대 개구량은 $15 \mathrm{~mm}$ 로 제한되었다. 턱관절 증상이 의심되어 턱관절 cone beam computed tomography (CBCT) 촬영을 하였고 좌측 과두부의 병적 골절, 과두 흡수 및 골수염 소견이 관찰되었다. 퇴원 2개월 후 temporomandibular joint (TMJ) magnetic resonance imaging (MRI), bone single photon emission computed tomography (SPECT)/CT 촬영 후에 외래 진료 시 TMJ maximum standardized uptake value (SUVmax) (Rt)의 uptake 소견은 2.98, TMJ SUVmax (Lt)의 uptake 소견이 13.42로 좌측에서 매우 높은 소견을 보였고 좌 측 하악지 및 과두의 골수염 소견과 함께 과두의 골절과 심한 흡 수가 관찰되었고 임상적으로는 최후방 대구치만 접촉되는 개
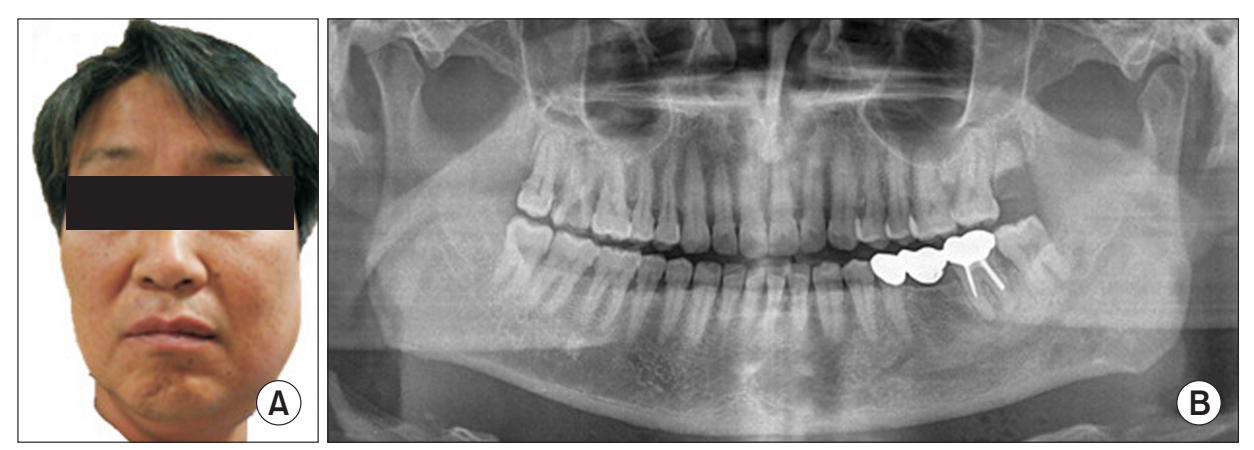

Fig. 5. (A) Progressive left cheek at the emergency department, (B) parnoramic radiograph at initial presentation. A removable partial denture was removed state. Note the periapical radiolucency on \#37 tooth. 

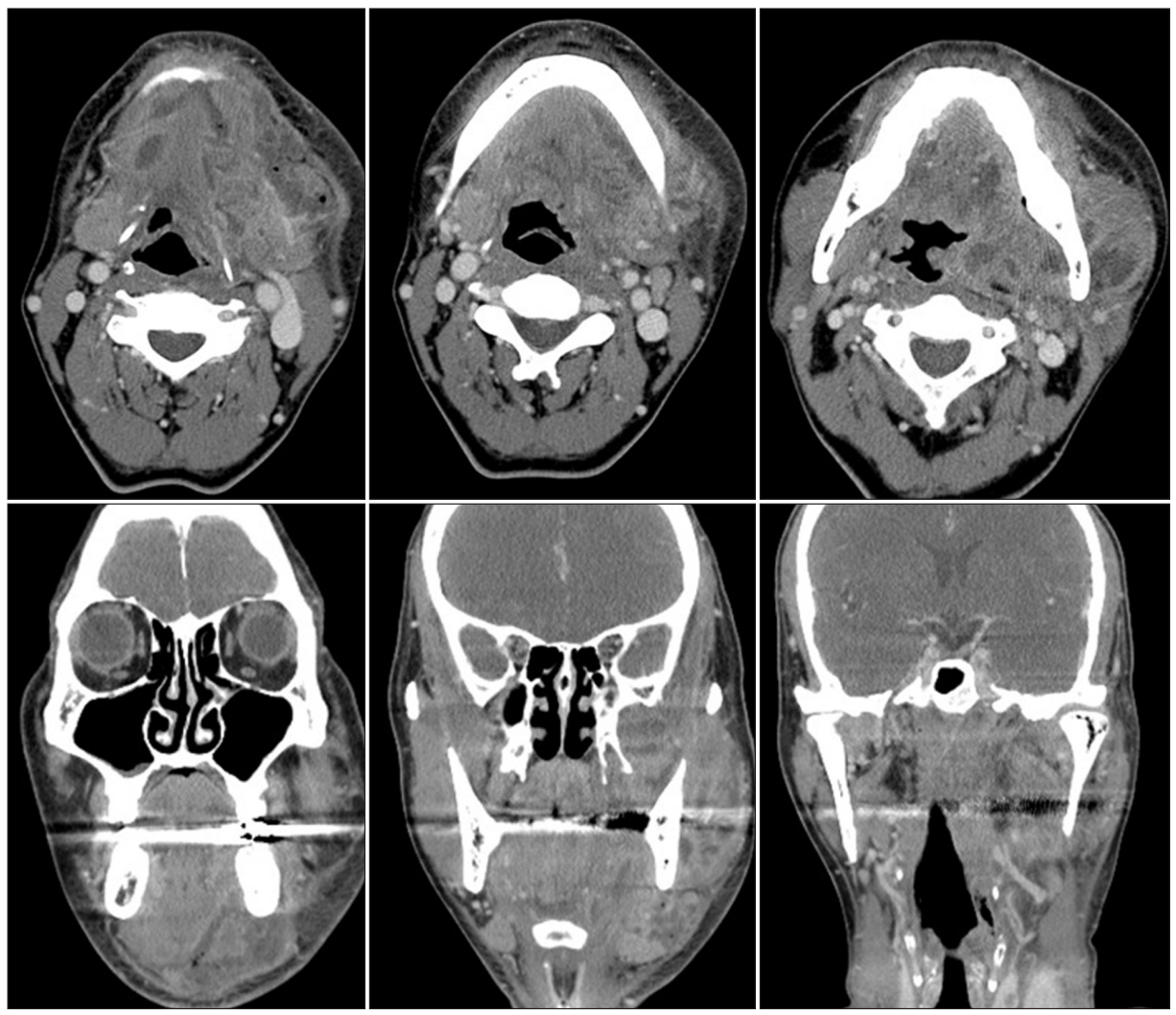

Fig. 6. The computed tomography scan showing the multiloculated abscess formation with emphysema around left mandibular body, submandibular, sublingual, masticator, parapharyngeal spaces, pterygoid muscles, submental, and chin area.
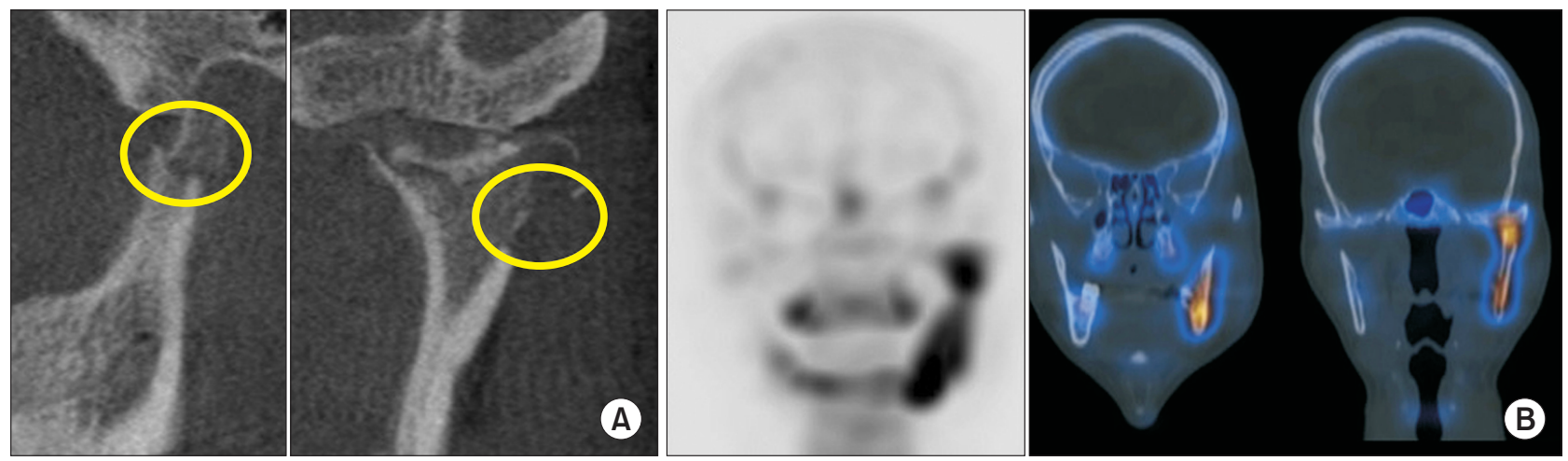

Fig. 7. (A) Temporomandibular joint cone beam computed tomography (CT) scan showing erosive lesion and pathologic fracture on left mandibular condyle. (B) BONE single photon emission computed tomography/CT view showing high uptake lesions on left mandibular ramus and condyle area. The uptake ratio was temporomandibular joint (TMJ) maximum standardized uptake value (SUVmax) (Rt) $=2.98$ and TMJ SUVmax $(\mathrm{Lt})=13.42$.

방 교합 양상을 보였다(Fig. 7). 매일 개구 운동을 지시하였고, 1 주 단위로 3회 내원하여 물리치료 및 개구 운동을 시행면서 clindamycin과 metronidazole을 3주간 투약하였다. 퇴원 3개 월 가량 되었을 때 수동적 최대 개구량은 $24 \mathrm{~mm}$ 까지 확보되었 다. 지속적인 치료가 필요한 상황이었으나, 환자와 연락이 두절 되면서 내원하지 않았다.

이후 수술 30개월 경과한 시점에 환자와 연락이 닿아 치과 외
래에 내원하였다. 그 동안 치과치료는 받지 못한 상태로, 자가 개구 운동만을 단기간 시행하고 방치된 상태였다. 최대 개구량 은 $29 \mathrm{~mm}$ 까지 확보된 상태로, 전치부 개방교합은 어느 정도 회 복되었으며, $\mathrm{CBCT}$ 촬영한 결과 좌측 과두는 골개조(bony remodeling)되어 있었다(Fig. 8). 골수염의 진행양상도 정지된 것 으로 보이며, 환자도 일상 생활에 특별한 불편감 없이 지내고 있 다고 해 치료를 종결하였다. 

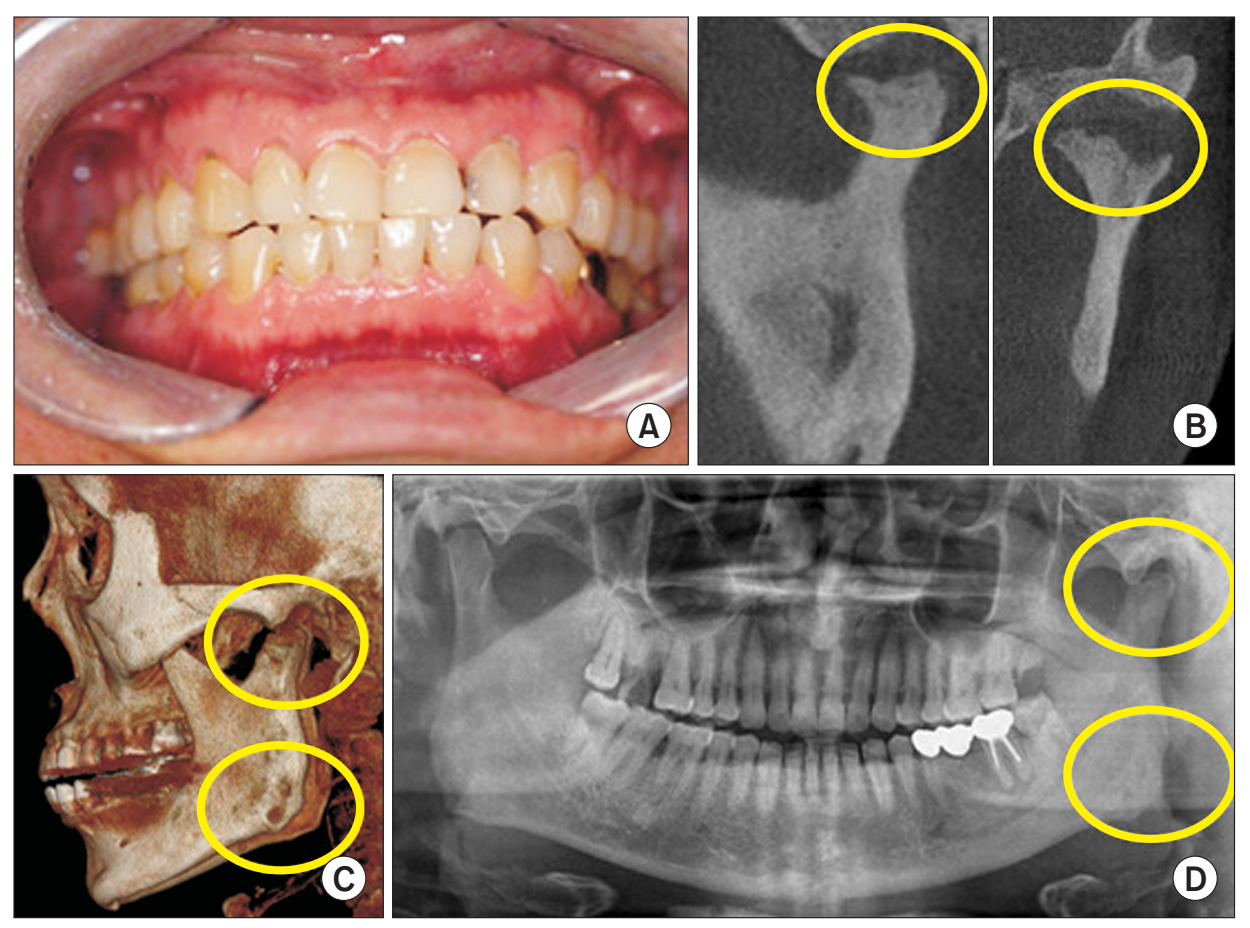

Fig. 8. (A) Stable occlusion showing no anterior openbite. (B) The computed tomography (CT) scan showing left condyle remodeling and cortical lining, (C) the reconstructive CT scan showing resorptive bony lesion, but healing state, (D) panorama radiograph at final observation (postoperative 30 months) showing bony healing.

\section{고 찰}

구강악안면 부위의 감염 원인으로는 크게 치성 감염과 비치 성 감염으로 구분할 수 있다. 치성감염은 치아 우식, 치수 감염, 치근단 병소, 지치 주위염, 치주 병소 등이 있으며, 구강악안면 부위 감염의 대부분의 원인을 차지한다 [5,11]. 치성 감염은 조직 저항이 적은 치조골이나 치근단 방향으로 우선 확산된 후에 화 농성 물질이 얇은 치밀골을 뚫고 골침식과 함께 연조직으로 파 급되면서 근막 간극을 침범하게 된다. 비치성 감염의 원인은 인 두나 편도, 타액선 등의 감염이나 주사침, 외상, 기타 외과적 수 술로 인한 감염 등을 들 수 있다[12].

감염에 대한 치료 원칙은 먼저 저하된 면역기능 및 전신상태 를 회복시키기 위해 수액 요법, 영양 보충이 필요하고, 충분한 기도 확보 및 유지가 필요하다. 적절한 항생제를 투약해야 하고, 외과적인 처치를 통해 확실한 배농 및 지속적인 배농의 유지가 필요하다. 또한, 가능한 빠르게 감염의 원인을 외과적으로 제거 해야 한다. 술 후 창상소독을 철저히 시행하여 회복양상을 지속 적으로 관찰하고, 개구량 회복 및 원활한 치유를 위한 개구 운동 이나 물리치료가 도움이 된다.

항생제의 효능이 많이 좋아지긴 하였으나, 배농에 실패하면 감염이 심화되거나 회복이 더딜 수 있고, 신속한 절개 및 배농 술을 통해 조직의 긴장도를 낮추어 염증 부위의 혈행 개선 및 면 역 기능 증진을 도모해야 한다[13]. 하지만 Kruger [14]는 절개 및 배농술의 시기를 농양이 진단되는 시기라고 하였고, 봉와직 염(cellulitis) 시기에서의 절개 및 배농술은 생리적 경계를 파괴 하여 감염을 확산시킬 수 있다고 보고했다. 반면에 Peterson [1] 은 기도확보와 유지, 고농도의 살균성 항생제의 정맥 투여와 함 께 감염 초기에 과감한 절개 및 배농술을 시행해야만 감염의 확 산을 막아 조기 치유를 보일 수 있다고 하였다. 본 연구에서 두 증례 모두 일차적인 항생제는 살균성 항생제인 ampicillin/sulbactam을 경험적으로 6시간 간격으로 투약하였고, 농배양과 항생제 감수성검사를 필요하다고 판단되는 경우마다 시행하여 항생제를 변경하거나, 감염내과와 협진하여 항생제를 선택하였 다.

치성 감염 환자에서 가장 빈번한 사망 원인은 상기도 폐쇄에 의한 호흡부전이다[15]. 따라서 진료의는 초기 환자 평가 시 이 러한 측면을 평가해야 하며, 치료 도중에도 급격한 증세 악화로 기도 폐쇄가 발생할 수 있기 때문에 특정 징후나 증상을 확인하 여 필요 시 즉시 기관절제술이나 기도 확보에 대한 응급대처 능 력을 가져야 한다. 감염이 진행된 해부학적 위치에 따른 위험 성 등급은 다음과 같다(Table 1) [16]. 본 연구의 증례들은 모두 severity score 1 에 해당되었다가 후인두간극까지 감염이 진행 되어 score 2 와 3 까지 심해진 난치성 감염이었다.

증례 1 의 환자의 경우에는 각종 기저질환이 많은 고령의 환자 로 특히 주의해야 하는 질환인 당뇨를 않고 있었다. 당뇨병을 가 진 경우에는 백혈구의 기능이 저하되고 신체 방어, 면역 기전이 약화되어 감염 유발률이 높고, 진행속도가 빠르고, 치료를 해도 창상 치유가 원활하지 않아 생명을 위협하기도 한다[17]. 내분 
Table 1. Severity scores for severe odontogenic infections according to anatomical space involvement

\section{Severity score}

Severity score $=1$ (mild risk for airway and/or vital structures)

Severity score $=2$ (moderate risk for airway and/or vital structures)

Severity score $=3$ (severe risk for airway and/or vital structures)

Severity score $=4$ (danger space) (extremely severe risk for airway and/or vital structures)
Anatomical space involved

Vestibular
Subperiosteal
Space of the body of the mandible
Infraorbital
Buccal
Submandibular
Submental
Sublingual
Pterygomandibular
Submasseteric
Superficial temporal
Deep temporal (or infratemporal)
Lateral pharyngeal or pterygopharyngeal
Retropharyngeal
Pretracheal
Prevertebral
Mediastinum
Intracranial infection

The severity score for a given subject is the sum of the severity scores for all of the spaces affected by cellulitis or with abscesses, based on the clinical and radiographic findings.

비 내과와 협진하여 인슐린 요법과 식이 조절로 혈당을 조절하 는 것이 감염 치료에 필수적이다.

다발성 전신질환 환자에서 난치성 치성 감염이 진행될 경우 절개 배농술 등의 국소마취하에 진행되는 치과 시술 자체가 출 혈과 동통증가를 초래하여 매우 위험할 수 있고, 극심한 통증을 호소하여 완벽한 배농이 어려운 경우가 많다[18]. 감염조직의 과도한 충혈과 혈관의 미란(erosion) 등으로 다량의 출혈이 발 생할 경우, 저혈량성 쇼크가 발생하여 생명을 위협하기도 한다 [15]. 따라서 심한 감염에 경우에는 응급상황이 발생하여도, 즉 각 대처가 가능하고 확실한 배농로 접근을 위해서는 전신마취 하에 수술을 진행하는 것이 바람직하다. 하지만, 대부분의 경우 $10 \mathrm{~mm}$ 내외로 극심한 개구제한이 동반되는 경우가 많으며, 이 런 경우 전신마취를 위한 삽관술이 매우 어렵기 때문에 마취과 전문의들은 자각상태 광섬유 삽관(awake fiber optic intubation)을 시도하거나, 전신마취하 수술을 꺼려하기도 한다. 이에 사전에 기도 평가를 위해 면밀한 검사가 필요할 수 있으며, 예방 적으로 기관절개술을 통해 기도를 확보하면 전신마취하 수술이 수월해질 수 있다. 본 연구의 증례에서도 두 환자 모두 저작간극 까지 감염의 진행이 확산되어 $10 \mathrm{~mm}$ 내외의 개구제한이 관찰 되어 전신마취 수술 및 술 후 기도유지를 위해 기관절개술을 시 행하여, 만일에 발생할 수 있는 응급상황을 예방하였다.

증례 2의 경우에 적극적인 치료로 일차적인 감염 증상이 해소 되어 퇴원했지만, 추후 이차적인 골파괴 병소가 관찰되면서 좌 측 하악지와 과두 부위의 골수염 소견, 좌측 과두의 병적 골절과
함께 과두 흡수가 진행되어 전치부 개방교합과 함께 최후방 대 구치만 교합되는 부정교합이 발생하였다. 개구량 회복을 위해 Therabite 등의 기구로 적극적인 하악 개구 운동을 시행하였고, soft laser 물리치료와 함께 약물치료를 병행하였으나, 1주에 1 번씩 총 3회만 내원하고 연락이 두절되어 향후 처치가 어려웠 다. 최종적으로 수술 30 개월 뒤에 관찰했을 때는 개구량 $29 \mathrm{~mm}$ 로 회복되었고 하악 과두의 골개조를 관찰할 수 있었고 교합도 안정적인 양상을 보였다. 수술 후 개구 운동, 물리치료 및 항생 요법 등의 지속적인 관리가 동반되었으면 최종적으로 보다 나 은 안정적인 교합과 개구량을 확보할 수 있었을 것으로 생각되 었으나 환자가 향후 치료를 희망하지 않아 치료를 종결하였고, 비용문제로 인해 추가적인 핵의학검사는 시행하지 못하였다.

치성 감염으로 인한 합병증으로 인해 종종 응급상황이 발생 하기도 한다. 본 연구의 증례들을 토대로 입원 시 타과와의 적극 적인 협진, 수술적 접근방법, 수술 전 후 처치, 퇴원 후 관리 등 전반적인 치료 경과에 관하여 진단과 치료 및 합병증 예방에 도 움이 되고자 문헌고찰과 함께 보고하는 바이다. 향후 심한 구강 악안면부 감염 환자들의 최적의 치료 방법의 가이드라인을 고 안하려는 다각도의 노력이 필요할 것으로 판단된다.

본 연구의 증례들에서도 감염 증상으로 응급실에 도착한 후 배농이 많이 되지 않았음에도 감압(decompression)을 위해 조 기에 절개 및 배농술을 시행하였다. 하지만 증상이 급속도로 악 화되어 상기도를 폐쇄하면서 호흡의 어려움까지 초래하는 상황 이 발생하여 조기 진단을 통한 응급 기관절개술을 시행해 생명 
을 위협하는 상황에 적절히 대처하였다. 이처럼 다발성 간극의 난치성 감염에서는 종종 응급 상황이 발생할 수 있으며, 다른 전 신질환들의 관리 및 영양 보충, 활력징후들을 면밀하게 관찰하 면서 타의과와의 협진이 필수적이다. 본 증례 2 의 환자는 분당 서울대학교병원에서 운영하는 SAFER team (SNUBH medical alert first responder)이 실시간으로 환자 상태를 관찰하여, 다 섯 차례의 설사, 두 차례의 토혈을 A4 용지 2장 크기 가량 배출 하였고, Hemoglobin은 5.9로 저하, prothrombin time (PT) 연 장 등의 징후를 보여 응급으로 경동맥혈관색전술 및 수혈을 통 해 생명을 유지할 수 있었다. 치과적으로도 조기에 절개 배농술 을 하고, 가능하면 완벽한 통증조절을 위해 전신마취하에서 확 실한 배농로를 확보하는 것이 필요하며, 퇴원 후에도 간혹 지연 성 감염이 발생하여 골수염을 초래하거나, 개구제한을 유발할 수 있어 잦은 내원을 통한 감염 조절 및 기능 회복을 위한 물리 치료 및 항생 요법이 동반되어야 할 것으로 생각된다.

\section{CONFLICTS OF INTEREST}

The authors declare that they have no competing interests.

\section{ORCID}

\author{
Dong-Woo Kang \\ https://orcid.org/0000-0002-0118-0053 \\ Pil-Young Yun \\ https://orcid.org/0000-0001-6097-1229 \\ Young-Kyun Kim \\ https://orcid.org/0000-0002-7268-3870
}

\section{REFERENCES}

1. Peterson LJ. Contemporary management of deep infections of the neck. J Oral Maxillofac Surg 1993;51:226-231. doi: 10.1016/s0278-2391(10)80162-4.

2. Kim GW, Kim KW, Kim SG, Kim YG, Kim JY, Kim HG, Min SK, Park YW, Park JW, HJ Park, JA Baek, HK Oh, YJ Yu, JH Yoo, JH Yun, SH Lee, JH Lee, HJ Jang. Oral \& maxillofacial infection. Seoul: Jee Sung Publishing Co.; 2007. p. 67-121.

3. Tavakoli M, Bagheri A, Faraz M, Salehirad S, Roghaee S. Orbital cellulitis as a complication of mandibular odontogenic infection. Ophthalmic Plast Reconstr Surg 2013;29:e5-e7. doi: 10.1097/IOP.0b013e318254132a.

4. Park MY, Kim HS, Ko HC, Kim MB, Kim BS. Infratemporal fossa abscess of dental origin: a rare, severe and misdi- agnosed infection. J Korean Assoc Oral Maxillofac Surg 2018;44:37-39. doi: 10.5125/jkaoms.2018.44.1.37.

5. Joo HH, Weon DW, Lee SH, Kim IH. A clinico-statistical analysis on the fascial space infections of oral and maxillofacial egion. J Korean Assoc Oral Maxillofac Surg 2000;26:490-496.

6. Baker KA, Fotos PG. The management of odontogenic infections. A rationale for appropriate chemotherapy. Dent Clin North Am 1994;38:689-706.

7. Thukral R, Shrivastav K, Mathur V, Barodiya A, Shrivastav S. Actinomyces: a deceptive infection of oral cavity. J Korean Assoc Oral Maxillofac Surg 2017;43:282-285. doi: 10.5125/ jkaoms.2017.43.4.282.

8. Sayd S, Vyloppilli S, Kumar K, Subash P, Kumar N, Raseel S. Comparison of the efficacy of amoxicillin-clavulanic acid with metronidazole to azithromycin with metronidazole after surgical removal of impacted lower third molar to prevent infection. J Korean Assoc Oral Maxillofac Surg 2018;44:103-106. doi: 10.5125/jkaoms.2018.44.3.103.

9. Flynn TR. Odontogenic infections. Oral Maxillofac Surg North Am 1991;3:311-329.

10. Walia IS, Borle RM, Mehendiratta D, Yadav AO. Microbiology and antibiotic sensitivity of head and neck space infections of odontogenic origin. J Maxillofac Oral Surg 2014;13:16-21. doi: 10.1007/s12663-012-0455-6.

11. Lee WH, Ahn KM, Jang BY, Ahn MR, Lee JY, Sohn DS. Clinicostatistical study of inpatients of abscess in fascial spaces for the last 5 years. J Korean Assoc Oral Maxillofac Surg 2004:30:497-503.

12. Lugo AFG, Ravago MGC, Martinez RAG, Peltrini RJZ. Ludwig's angina: a report of two cases. Revista Española de Cirugía Oral y Maxilofacial 2014;36:177-181.

13. Falace DA. Emergency dental care : diagnosis and management of urgent dental problems. Baltimore: Williams and Wilkins; 1995. pp. 209-226.

14. Kruger GO. Textbook of oral and maxillofacial surgery. 6th ed. St. Louis: CV Mosby; 1986.782 p.

15. Kim MK, Nalliah RP, Lee MK, Allareddy V. Factors associated with length of stay and hospital charges for patients hospitalized with mouth cellulitis. Oral Surg Oral Med Oral Pathol Oral Radiol 2012;113:21-28. doi: 10.1016/ j.tripleo.2011.01.012.

16. Flynn TR, Shanti RM, Levi MH, Adamo AK, Kraut RA, Trieger N. Severe odontogenic infections, part 1: prospective report. J Oral Maxillofac Surg 2006;64:1093-1103. doi: 10.1016/j.joms.2006.03.015.

17. Laskin DM. Systemic effects of oral infections: a possible preventive role for the oral and maxillofacial surgeon. J Oral Maxillofac Surg 2001;59:853. doi: 10.1053/ joms.2001.26040.

18. Little JW, Falace DA. Dental management of the medically compromised patient. 6th ed. St. Louis: Mosby; 2002. pp. 332-64, 501-525. 